\title{
Production of Cocoa Butter Replacer by Dry Fractionation, Partial Hydrogenation, Chemical and Enzymatic Interesterification of Tea Seed Oil
}

\author{
Soheila Zarringhalami, Mohammad Ali Sahari*, Mohsen Barzegar, Zohreh Hamidi-Esfehani \\ Food Technology Department, College of Agriculture, Tarbiat Modares University, Tehran, Iran. \\ Email: ${ }^{*}$ sahari@modares.ac.ir
}

Received October 31 $1^{\text {st }}, 2011$; revised December $19^{\text {th }}, 2011$; accepted December $26^{\text {th }}, 2011$

\begin{abstract}
Production of cocoa butter replacer (CBR) from tea seed oil through common modification methods of oils (dry fractionation, partial hydrogenation, chemical and enzymatic interesterification) was evaluated. Some physico-chemical properties (iodine, saponification, acid and peroxide values) and fatty acid composition (FAC) of modified samples were analyzed and compared with a reference cocoa butter (CB). Solid and liquid fractions for large amounts of unsaturated fatty acids (approx. 80\%) and thereby lower iodine values $\left(81-85 \mathrm{gI}_{2} / 100 \mathrm{~g}\right)$ than that of $\mathrm{CB}(37 \%$ and 34 $\mathrm{gI}_{2} / 100 \mathrm{~g}$, respectively), are not suitable as CBR. Among all ratios of chemically and enzaymatically interesterified oil blends $(20 \%, 25 \%$ and $30 \%$ of hydrogenated tea seed oil with $80 \%, 75 \%$ and $70 \%$ of tea seed oil/liquid fraction/solid fraction), the samples with ratio of 30:70 from both chemical and enzymatic interesterification had FAC and iodine value closer to that of CB. A comparision between chemically and enzymatically interesterified samples (CISs and EISs, respectively), in terms of solid fat content (SFC) indicated that although the SFC values in EIS were much lower than that of $\mathrm{CB}$, but the thermal behavior of this sample is comprable to $\mathrm{CB}$ at $20^{\circ} \mathrm{C}-30^{\circ} \mathrm{C}$ (sharp melting point of $\mathrm{CB}$ ).
\end{abstract}

Keywords: Cocoa Butter Replacer; Tea Seed Oil; Dry Fractionation; Partial Hydrogenation; Interesterification

\section{Introduction}

Cocoa butter (CB) is an essential ingredient in chocolate and related confectionary products because of its more influence on sensory and physico-chemical properties in these applications. However, high price and uncertainty in supply of $\mathrm{CB}$ in view of rising worldwide demand, lead to production of CBRs from available and cheap commercial oils or fats [1].

The beverage tea plant (Camellia olifera Able.) that is mainly cultivated in the north of Iran produces large amounts of seed as by-product. Whereas, the oil content of tea seed is about $30 \%-32 \%$. Moreover, tea seed oil is high quality edible oil, like olive oil, and excellent storage quality because of the high polyphenols content as antioxidant agents [2,3]. Several studies have been developed on tea seed oil compositions and its application in food products. Oleic (C18:1), linoleic (C18:2), palmitic $(\mathrm{C} 16: 0)$ and stearic $(\mathrm{C} 18: 0)$ acids, are the major fatty acids of tea seed oil $[2,4]$. This oil also is a good raw material to produce margarine and cocoa butter equivalent $[5,6]$, but like other vegetable oils tea seed oil has only limited commercial applications in its original ${ }^{*}$ Corresponding author. form.

Vegetable oils are usually modified by fractionation, hydrogenation and chemical or enzymatic interesterification to improve their commercial applications [5]. The purpose of fractionation is the separation of triacylglycerols on the basis of the melting points. Three methods have been used industrially in the fractionation process: dry, solvent and aqueous fractionation, that among these methods, the dry fractionation is the simplest and economical $[7,8]$. Modification of oils by hydrogenation has been used industrially for many years. In this reaction double bounds are reduced to single bounds, which increase melting point of oils [9]. Chemical and enzymatic interesterification is used for modifying the physicochemical properties of oils and fats with exchange fatty acids within and among triacylglycerols [5].

These modification methods were studied to produce structured lipid such as CBRs, from available oils or fats for many years.

The main objective of this study was to modify tea seed oil by dry fractionation, partial hydrogenation, chemical and enzymatic interesterification and to choose proper method to produce CBR. 


\section{Materials and Methods}

Tea seeds (Lahijan variety), were harvested from Iranian farms in Lahijan (located in the Northern part of Iran). Lypozim TL IM, a silica granulated Thrmomyces lanuginosus, which is 1,3-specific lipase, and a sample of Malaysian CB were donated by Novozymes A/S (Bagsvaerd, Denmark) and Minoo chocolate factory (Tehran, Iran), respectively. All of chemicals used in this study were purchased from Merck (Darmstadt, Germany).

\subsection{Oil Extraction}

After collection from the farms and handling to the laboratory, tea seeds were oven dried at $102^{\circ} \mathrm{C}$ (moisture $=$ $15 \%$ ) and the oil was extracted by the solvent method after grounding the seeds. Solvent (hexane) was then recovered in rotary evaporator at maximum temperature of $60^{\circ} \mathrm{C}$ [5]. The oil was held at $4^{\circ} \mathrm{C}$ before analysis.

In order to produce a sample with properties closer to that of $\mathrm{CB}$ from tea seed oil, the common modification methods of oils and fats (dry fractionation, partial hydrogenation, chemical and enzymatic interesterification) were initially done.

\subsection{Dry Fractionation}

Tea seed oil remains liquid even at refrigerated temperature. Hence, dry fractionation of tea seed oil was carried out in a Test Chamber (Binder, Germany) at $-20^{\circ} \mathrm{C}$ with 20 - $30 \mathrm{rpm}$ mixing rate (a mixer equipped with rate controller was located in the Test Chamber) during $4 \mathrm{~h}$. After this time two prepared fractions (liquid and solid) then separated by centrifugation at $10,000 \mathrm{~g}$ for $10 \mathrm{~min}$ at $-20^{\circ} \mathrm{C}$.

\subsection{Partial Hydrogenation}

Hydrogenation of tea seed oil was done in a laboratory reactor (Zero Max, USA) until m.p. of $31^{\circ} \mathrm{C}$ (as a replacer for $\mathrm{CB}$ ) and $47^{\circ} \mathrm{C}$ (as a stock base to produce $\mathrm{CB}$ in combination with other modification methods). Operating conditions in this process were adjusted as: temperature $175^{\circ} \mathrm{C}-180^{\circ} \mathrm{C}$, pressure: $20 \mathrm{psi}$, mixing rate 350 - $400 \mathrm{rpm}$ and Ni catalyst (Nysosel 800, BASF company, Netherlands) $0.4 \%$ by weigh of oil [5].

\subsection{Blend Preparation}

Oil samples for interesterification process were prepared with blending hydrogenated tea seed oil $\left(\mathrm{m} . \mathrm{p}=47^{\circ} \mathrm{C} ; 20\right.$, 25 and 30$)$ with tea seed oil $(80,75$ and 70$)$, solid fraction (80, 75 and 70) and liquid fraction (80, 75 and 70), at weigh percent ratios of 20:80, 25:75 and 30:70. The blends were then heated at $95^{\circ} \mathrm{C}$ for 45 min under vacuum conditions to remove any moisture and air [5].

\subsection{Chemical Interesterification}

Chemical interesterification of the oil blends were performed in a rotary evaporator (Heidolf, Schwabach, Germany) at $120^{\circ} \mathrm{C}$ for $60 \mathrm{~min}$, with $\mathrm{NaOH}$ catalyst $(1 \%$ $\mathrm{w} / \mathrm{w})$. The reaction was then stopped by addition of citric acid solution $(20 \% \mathrm{w} / \mathrm{v})$ after cooling of the interesterified samples approx. $60^{\circ} \mathrm{C}$. The excess of citric acid and catalyst were removed by warm water washes $(3 \times 150$ $\mathrm{mL})$. Then the modified samples were stored at $-24^{\circ} \mathrm{C}$ until further analysis $[5,10]$.

\subsection{Enzymatic Interesterification}

Enzymatic interesterification of the oil blends were carried out in screw-capped vials fitted with a magnetic stirring bar. Operating conditions were set as: temperature $60^{\circ} \mathrm{C}$, stirring rate $700 \mathrm{rpm}$, reaction time $8 \mathrm{~h}$ and enzyme dosage $10 \%$ by weigh of oil [11].

\subsection{Physico-Chemical Properties}

Some physico-chemical properties such as saponification value $(\mathrm{SV})$, acid value $(\mathrm{AV})$ and peroxide value $(\mathrm{PV})$ were determined by AOCS methods; Iodine vale (IV) by Hanus method and eventually m.p. closed capillary tube method (AOCS, method No. Cc 1-25) [12].

\subsection{GC Analysis for FAC}

FAC was determined after conversion of fatty acids into corresponding methyl esters [13] prior to analysis by GC (Unicam 4600, UK) equipped with flame ionization detector (FID), split-injection port $(0.2 \mu 1$ injection) and a fused silica capillary column (BPX70; SGE, Melbourne, Australia) with $30 \mathrm{~m} \times 0.25 \mathrm{~mm} \times 0.22 \mu \mathrm{m}$ film thickness. The carrier gas was Helium (pressure of 20 psi) and working temperature of the injector and detector were 250 and $270^{\circ} \mathrm{C}$, respectively. The initial column temperature was set at $160^{\circ} \mathrm{C}$ for $6 \mathrm{~min}$ and rose to $180^{\circ} \mathrm{C}\left(6^{\circ} \mathrm{C} / \mathrm{min}\right)$ and thereafter increased to $200^{\circ} \mathrm{C}$ $\left(20^{\circ} \mathrm{C} / \mathrm{min}\right)$.

\subsection{SFC of the Oil Samples}

A Bruker minispec NMR (Karlsruhe, Germany) was employed for the SFC measurement. The samples were tempered at $60^{\circ} \mathrm{C}$ for $5 \mathrm{~min}$, followed by cooling at $0^{\circ} \mathrm{C}$ for $60 \mathrm{~min}$ prior to analysis. During this study the samples were evaluated at intervals of $5^{\circ} \mathrm{C}$ between $5^{\circ} \mathrm{C}$ and $45^{\circ} \mathrm{C}$.

\subsection{Statistical Analysis}

Analysis of variance and Duncan's multiple range tests were performed using SPSS software to evaluate the significance of differences between mean from triplicate 
analysis at the level of $P<0.05$.

\section{Results and Discussions}

Physico-chemical properties and FAC of two fractions of tea seed oil (liquid and solid) and hydrogenated tea seed oil $\left(\mathrm{mp}=31^{\circ} \mathrm{C}\right)$ in comparison with $\mathrm{CB}$ are given in Table 1. The differences between IVs in two fractions, hydrogenated and nonhydrogenated tea seed oil were significant $(P<0.05)$, but SVs and AVs showed no significant difference and PV in tea seed oil and two fractions not detected. The IV correlates well with the overall of fatty acid analysis. Based on the results in Table 1, if the stearic acid is decreased and oleic and linoleic acids are increased in liquid fraction, the IV increased in comparison with solid fraction and hydrogenated tea seed oil [10]. Based on the fact that the IV and FAC indicate degree of hardness or softness of oils and fats, these samples have very softer texture than of CB [14]. Moreover, the trans-isomer in hydrogenated tea seed oil is very high $(53.36 \%)$, which can increase coronary heart diseases [5]. Therefore, dry fractionation and partial hydrogenation are not suitable methods for production of a sample as CBR. These results are in contrast with Tang et al. [15] who reported that tea seed oil after hydrogenation could be used as CBR.

In order to get better results and produce samples with closer properties to $\mathrm{CB}$, dry fractionation and partial hydrogenation were used in combination with chemical and enzymatic interesterification.

Table 2 shows the m.p. of oil blends before and after interesterification in comparison with CB. Depending on the geographical origin of cocoa plant, m.p. of $\mathrm{CB}$ lies between $31^{\circ} \mathrm{C}$ and $36^{\circ} \mathrm{C}$ [16]. The m.p. of $\mathrm{CB}$ that was used in our study was $31.4^{\circ} \mathrm{C}$. According to the results in Table 2, the m.p. of all samples are decreased $\left(4^{\circ} \mathrm{C}-6^{\circ} \mathrm{C}\right)$ after chemical and enzymatic interesterification. Our findings generally agree with those reported by Fattahi-far et al. [5] and Osborn and Akoh, [16] who showed that the m.p. of oil blends decreased after chemical and enzymatic interesterification, respectively. Table 2 also illustrates that among all samples after chemical interesterification, the samples with ratio of 30:70, had the m.p. closer to that of $\mathrm{CB}$, but after enzymatic interesterification the m.p. of all samples was almost within this range. In chocolate products, the interesterified samples should melt fast and completely at body temperature $\left(37^{\circ} \mathrm{C}\right)$. Although all of CISs and EISs have m.p. lower than $37^{\circ} \mathrm{C}$, in the case of CBRs if the m.p. is lower or higher than the range that of $\mathrm{CB}\left(31^{\circ} \mathrm{C}-36^{\circ} \mathrm{C}\right)$, the quality of final products (chocolate and confectionary products contain CB) would be adversely affected $[10,17]$.

Physico-chemical properties of the interesterified samples are presented in Table 3 . The results show that there is no significant difference $(P>0.05)$, between SVs, AVs and PVs, but the IV alterations are significant $(P<$ $0.05)$ among these samples. Since SV indicates molecular weight of fatty acids in triacylglycerol structure, and interesterification does not affect on fatty acid composition of the starting oil samples [10], this value (SV) shows no significant difference among interesterified

Table 1. Physico-chemical properties and fatty acid composition of tea seed oil, liquid and solid fractions and hydrogenated tea seed oil $\left(\mathrm{mp}=33^{\circ} \mathrm{C}\right)$ in comparison with cocoa butter (mean \pm standard deviation of triplicate analysis).

\begin{tabular}{|c|c|c|c|c|c|}
\hline Oil samples & Tea seed oil & $\begin{array}{c}\text { Liquid } \\
\text { fraction }\end{array}$ & $\begin{array}{c}\text { Solid } \\
\text { fraction }\end{array}$ & $\begin{array}{l}\text { Hydrogenated } \\
\text { tea seed oil }\end{array}$ & Cocoa butter \\
\hline $\mathrm{IV}\left(\mathrm{gI}_{2} / 100 \mathrm{~g}\right)$ & $83.73 \pm 0.25^{\mathrm{b}}$ & $85.10 \pm 1.01^{\mathrm{a}}$ & $81.53 \pm 0.12^{\mathrm{c}}$ & $67.87 \pm 0.78^{\mathrm{d}}$ & $34.9 \pm 0.36^{\mathrm{e}}$ \\
\hline $\mathrm{SV}(\mathrm{mg} \mathrm{KOH} / \mathrm{g})$ & $192.37 \pm 0.74^{b}$ & $192.43 \pm 0.90^{\mathrm{b}}$ & $192.60 \pm 0.45^{\mathrm{b}}$ & $193.30 \pm 0.82^{b}$ & $197.23 \pm 1.97^{\circ}$ \\
\hline $\mathrm{AV}(\mathrm{mg} \mathrm{NaOH} / \mathrm{g})$ & $0.51 \pm 0.19^{b}$ & $0.40 \pm 0.05^{\mathrm{b}}$ & $0.50 \pm 0.08^{\mathrm{b}}$ & $0.48 \pm 0.03^{\mathrm{b}}$ & $1.04 \pm 0.06^{\mathrm{a}}$ \\
\hline $\mathrm{PV}\left(\right.$ meq $\mathrm{O}_{2} / \mathrm{kg}$ ) & ND & ND & ND & $0.55 \pm 0.06^{\mathrm{b}}$ & $1.00 \pm 0.10^{\mathrm{a}}$ \\
\hline \multicolumn{6}{|l|}{ FAC (\%) } \\
\hline Palmitic acid (C16:0) & $17.40 \pm 0.10^{\mathrm{bc}}$ & $17.21 \pm 0.01^{\mathrm{c}}$ & $17.53 \pm 0.18^{b}$ & $17.37 \pm 0.42^{\mathrm{bc}}$ & $25.76 \pm 0.04^{\mathrm{a}}$ \\
\hline Stearic acid (C18:0) & $4.30 \pm 0.10^{\mathrm{c}}$ & $2.59 \pm 0.06^{\mathrm{e}}$ & $4.07 \pm 0.04^{\mathrm{d}}$ & $9.13 \pm 0.11^{b}$ & $34.88 \pm 0.12^{\mathrm{a}}$ \\
\hline Oleic acid (C18:1 cis) & $55.96 \pm 0.05^{\mathrm{b}}$ & $57.10 \pm 0.28^{\mathrm{a}}$ & $55.83 \pm 0.04^{\mathrm{b}}$ & $10.32 \pm 0.30^{\mathrm{d}}$ & $33.68 \pm 0.18^{\mathrm{c}}$ \\
\hline Elaidic acid (C18:1 trans) & & & & $53.36 \pm 0.03$ & \\
\hline Linoleic acid (C18:2) & $21.15 \pm 0.05^{\mathrm{c}}$ & $22.00 \pm 0.14^{\mathrm{a}}$ & $21.50 \pm 0.12^{\mathrm{b}}$ & $9.07 \pm 0.26^{\mathrm{d}}$ & $3.90 \pm 0.10^{\mathrm{e}}$ \\
\hline Others & $1.19 \pm 0.00^{\mathrm{b}}$ & $1.11 \pm 0.09^{\mathrm{c}}$ & $1.08 \pm 0.03^{\mathrm{c}}$ & $0.77 \pm 0.08^{\mathrm{d}}$ & $1.80 \pm 0.01^{\mathrm{a}}$ \\
\hline
\end{tabular}

Means within row with no common superscripts $(\mathrm{a}-\mathrm{e})$ are significantly different $(P<0.05)$ according to LSD test. IV, iodine value; SV, saponification value; $\mathrm{AV}$, acid value; PV, peroxide value; FAC, fatty acid composition; ND, not detected. 
Table 2. Melting point of oil blends before (B) and after chemical (C) and enzymatic (E) interesterification in comparison with cocoa butter.

\begin{tabular}{|c|c|c|c|c|}
\hline Oil blends & & m.p. $\left({ }^{\circ} \mathrm{C}\right)$ & & \\
\hline & & B & C & $\mathbf{E}$ \\
\hline \multirow[t]{3}{*}{$\mathrm{H} / \mathrm{L}$} & $20: 80$ & $35.73 \pm 0.06^{\mathrm{a}}$ & $28.87 \pm 0.32^{\mathrm{c}}$ & $31.53 \pm 0.06^{\mathrm{b}}$ \\
\hline & $25: 75$ & $36.47 \pm 0.06^{\mathrm{a}}$ & $29.30 \pm 0.10^{c}$ & $31.73 \pm 0.21^{b}$ \\
\hline & $30: 70$ & $36.83 \pm 0.06^{\mathrm{a}}$ & $30.37 \pm 0.15^{c}$ & $31.93 \pm 0.06^{b}$ \\
\hline \multirow[t]{3}{*}{$\mathrm{H} / \mathrm{S}$} & $20: 80$ & $35.03 \pm 0.06^{\mathrm{a}}$ & $29.17 \pm 0.06^{c}$ & $31.30 \pm 0.10^{b}$ \\
\hline & $25: 75$ & $36.00 \pm 0.10^{\mathrm{a}}$ & $30.67 \pm 0.15^{\mathrm{c}}$ & $31.83 \pm 0.06^{b}$ \\
\hline & $30: 70$ & $36.93 \pm 0.06^{\mathrm{a}}$ & $31.03 \pm 0.12^{\mathrm{c}}$ & $32.23 \pm 0.25^{b}$ \\
\hline \multirow[t]{3}{*}{$\mathrm{H} / \mathrm{O}$} & $20: 80$ & $35.53 \pm 0.06^{\mathrm{a}}$ & $29.17 \pm 0.06^{c}$ & $30.26 \pm 0.06^{b}$ \\
\hline & $25: 75$ & $36.40 \pm 0.10^{\mathrm{a}}$ & $29.70 \pm 0.44^{\mathrm{c}}$ & $30.47 \pm 0.06^{b}$ \\
\hline & $30: 70$ & $36.87 \pm 0.06^{\mathrm{a}}$ & $30.03 \pm 0.06^{\mathrm{c}}$ & $32.03 \pm 0.06^{b}$ \\
\hline $\mathrm{CB}$ & & $31.43 \pm 0.12$ & & \\
\hline
\end{tabular}

$\mathrm{H} / \mathrm{L}, \mathrm{H} / \mathrm{S}$ and $\mathrm{H} / \mathrm{O}$ ratio of hydrogenated tea seed oil $\left(\mathrm{m} . \mathrm{p} .=47^{\circ} \mathrm{C}\right)$ and liquid fraction, solid fraction and tea seed oil, respectively; Each value in the table represents the mean \pm standard deviation of triplicate analysis; Different superscripts within a row represent significant difference at $P<0.05$.

Table 3. Physico-chemical properties of interesterified samples in comparison with cocoa butter.

\begin{tabular}{|c|c|c|c|c|c|}
\hline Interesterified samples & & IV (gI $/ \mathbf{1 0 0 g})$ & SV (mg KOH/g) & $\mathrm{AV}$ (mg NaOH/g) & PV $\left(\right.$ meq $\left.\mathrm{O}_{2} / \mathbf{k g}\right)$ \\
\hline \multirow[t]{3}{*}{$\mathrm{H} / \mathrm{L}$} & $20: 80$ & $68.27 \pm 0.71^{\mathrm{a}}$ & $193.33 \pm 1.04^{\mathrm{b}}$ & $0.99 \pm 0.10^{\mathrm{a}}$ & $0.50 \pm 0.10^{\mathrm{b}}$ \\
\hline & $25: 75$ & $65.43 \pm 0.45^{\mathrm{c}}$ & $191.83 \pm 2.39^{b}$ & $1.09 \pm 0.11^{\mathrm{a}}$ & $0.53 \pm 0.12^{b}$ \\
\hline & $30: 70$ & $61.20 \pm 1.18^{\mathrm{e}}$ & $191.40 \pm 1.71^{\mathrm{b}}$ & $1.03 \pm 0.12^{\mathrm{a}}$ & $0.50 \pm 0.10^{\mathrm{b}}$ \\
\hline \multirow[t]{3}{*}{$\mathrm{H} / \mathrm{S}$} & $20: 80$ & $66.83 \pm 0.76^{\mathrm{b}}$ & $192.27 \pm 0.75^{\mathrm{b}}$ & $1.09 \pm 0.11^{\mathrm{a}}$ & $0.60 \pm 0.10^{\mathrm{b}}$ \\
\hline & $25: 75$ & $63.67 \pm 1.04^{\mathrm{d}}$ & $191.17 \pm 1.31^{b}$ & $1.06 \pm 0.12^{\mathrm{a}}$ & $0.57 \pm 0.06^{\mathrm{b}}$ \\
\hline & $30: 70$ & $59.50 \pm 0.10^{\mathrm{f}}$ & $192.30 \pm 0.70^{\mathrm{b}}$ & $1.03 \pm 0.06^{\mathrm{a}}$ & $0.60 \pm 0.10^{\mathrm{b}}$ \\
\hline \multirow[t]{3}{*}{$\mathrm{H} / \mathrm{O}$} & $20: 80$ & $67.23 \pm 0.25^{\mathrm{ab}}$ & $193.03 \pm 1.29^{b}$ & $1.17 \pm 0.12^{\mathrm{a}}$ & $0.53 \pm 0.06^{\mathrm{b}}$ \\
\hline & $25: 75$ & $66.90 \pm 0.26^{\mathrm{b}}$ & $191.87 \pm 2.35^{\mathrm{b}}$ & $1.20 \pm 0.10^{\mathrm{a}}$ & $0.53 \pm 0.06^{b}$ \\
\hline & $30: 70$ & $60.60 \pm 1.11^{\mathrm{ef}}$ & $192.07 \pm 0.90^{\mathrm{b}}$ & $1.13 \pm 0.06^{\mathrm{a}}$ & $0.57 \pm 0.06^{\mathrm{b}}$ \\
\hline $\mathrm{CB}$ & - & $34.90 \pm 0.36^{\mathrm{g}}$ & $197.23 \pm 1.97^{\mathrm{a}}$ & $1.04 \pm 0.06^{\mathrm{a}}$ & $1.00 \pm 0.10^{\mathrm{a}}$ \\
\hline
\end{tabular}

Each value in the Table represents the mean \pm standard deviation of triplicate analysis. Different superscripts within a column represent significant difference at $P<0.05$. c, cis-isomers; t, trans-isomer; $\mathrm{H} / \mathrm{L}, \mathrm{H} / \mathrm{S}$ and $\mathrm{H} / \mathrm{O}$, ratios of hydrogenated tea seed oil $\left(\mathrm{mp}=47^{\circ} \mathrm{C}\right)$ and liquid fraction, solid fraction and tea seed oil, respectively; $\mathrm{CB}$, cocoa butter.

samples. AV and PV increase with unsuitable storage conditions (high temperature and humidity) in oil samples. Since, in this study, all of the oil samples were stored in $-24^{\circ} \mathrm{C}$ before and after interesterification, these values didn't change significantly. Interesterification does not affect the degree of saturation [10]. Because of this, differences in the IVs are due to the degree of saturation of oils used in each blend. Also, according to Table 3, among the physico-chemical properties the SVs, AVs and PVs were found to be close to that of $\mathrm{CB}$ although some were a little lower than $\mathrm{CB}$, all showed acceptable values. But, about IVs just the samples with ratio of 30:70 showed the closer IVs to that of CB in comparison with other samples. Thus, these samples were selected for more evaluations.

The FAC of interesterified samples in ratio of 30:70 and CB, are presented in Table 4. The results show that interesterification didn't alter FAC. Hence, the FAC of samples from chemical and enzymatic interesterification didn't show significant difference $(P>0.05)$. These results were in accordance with those of Karabulut et al. [10] who observed that the fatty acids profile of oil 
Table 4. Fatty acid composition of hydrogenated tea seed oil (m.p. $\left.47^{\circ} \mathrm{C}\right)$ interesterified samples (30:70 ratios) and cocoa butter (mean \pm standard deviation of triplicate analysis).

\begin{tabular}{ccccccc}
\hline FAC (\%) & $\mathbf{( C 1 6 : 0 )}$ & $\mathbf{( C 1 8 : 0 )}$ & $\mathbf{( C 1 8 : 1 c i s )}$ & $\mathbf{( C 1 8 : 1 \text { trans) }}$ & (C18:2) & Others \\
\hline HTO & $17.61 \pm 0.19$ & $42.48 \pm 0.02$ & $16.71 \pm 0.09$ & $22.10 \pm 0.12$ & $0.11 \pm 0.01$ & $1.00 \pm 0.01$ \\
CISs & & & & & \\
H/L & $17.40 \pm 0.20^{\mathrm{b}}$ & $15.84 \pm 0.14^{\mathrm{d}}$ & $45.26 \pm 0.02^{\mathrm{a}}$ & $5.62 \pm 0.12^{\mathrm{b}}$ & $15.03 \pm 0.03^{\mathrm{a}}$ & $0.86 \pm 0.20^{\mathrm{d}}$ \\
H/S & $17.58 \pm 0.00^{\mathrm{b}}$ & $16.89 \pm 0.07^{\mathrm{b}}$ & $44.63 \pm 0.06^{\mathrm{b}}$ & $5.63 \pm 0.03^{\mathrm{b}}$ & $14.20 \pm 0.05^{\mathrm{c}}$ & $1.09 \pm 0.03^{\mathrm{b}}$ \\
H/O & $17.45 \pm 0.08^{\mathrm{b}}$ & $16.05 \pm 0.06^{\mathrm{c}}$ & $45.23 \pm 0.13^{\mathrm{a}}$ & $5.85 \pm 0.06^{\mathrm{a}}$ & $14.50 \pm 0.10^{\mathrm{b}}$ & $0.94 \pm 0.15^{\mathrm{cd}}$ \\
EISs & & & & & \\
H/L & $17.41 \pm 0.20^{\mathrm{b}}$ & $15.86 \pm 0.04^{\mathrm{d}}$ & $45.20 \pm 0.20^{\mathrm{a}}$ & $5.65 \pm 0.25^{\mathrm{ab}}$ & $15.00 \pm 0.15^{\mathrm{a}}$ & $0.89 \pm 0.06^{\mathrm{d}}$ \\
H/S & $17.58 \pm 0.02^{\mathrm{b}}$ & $16.89 \pm 0.09^{\mathrm{b}}$ & $44.56 \pm 0.05^{\mathrm{b}}$ & $5.70 \pm 0.10^{\mathrm{ab}}$ & $14.24 \pm 0.01^{\mathrm{c}}$ & $1.03 \pm 0.07^{\mathrm{bc}}$ \\
H/O & $17.42 \pm 0.10^{\mathrm{b}}$ & $16.08 \pm 0.02^{\mathrm{c}}$ & $45.28 \pm 0.08^{\mathrm{a}}$ & $5.71 \pm 0.00^{\mathrm{ab}}$ & $14.48 \pm 0.13^{\mathrm{b}}$ & $1.04 \pm 0.08^{\mathrm{bc}}$ \\
CB & $25.76 \pm 0.04^{\mathrm{a}}$ & $34.88 \pm 0.12^{\mathrm{a}}$ & $33.68 \pm 0.18^{\mathrm{c}}$ & $\mathrm{ND}$ & $3.90 \pm 0.10^{\mathrm{d}}$ & $1.80 \pm 0.01^{\mathrm{a}}$ \\
\hline
\end{tabular}

Means within column with no common superscripts $(\mathrm{a}-\mathrm{d})$ are significantly different $(P<0.05)$ according to LSD test. FAC, fatty acid composition; HTO, hydrogenated tea seed oil $\left(\mathrm{mp}=47^{\circ} \mathrm{C}\right)$; CISs, chemically interesterified samples; $\mathrm{H} / \mathrm{L}, \mathrm{H} / \mathrm{S}$ and $\mathrm{H} / \mathrm{O}$ ratio of hydrogenated tea seed oil $\left(\mathrm{mp}=47^{\circ} \mathrm{C}\right)$ and liquid fraction, solid fraction and tea seed oil, respectively; EISs, enzymatically interesterified samples; CB, cocoa butter; ND, not detected.

blends didn't change during interesterification reaction. The results also show that the samples that contain solid fraction $(30 \%$ of hydrogenated tea seed oil and $70 \%$ solid fraction; low trans-isomer: approx. 5.7\%) from chemical and enzymatic interesterification have FAC closer to that of CB. However, in these samples the palmitic and stearic acids are lower and the oleic and linoleic acids are higher compared with that of $\mathrm{CB}$. Regarding the results presented in Table 2, we conclude that the samples from enzymatic interesterification have m.p. within the range of m.p. of CB. This conclusion came with a hypothesis of having samples with better structural properties and thereby better thermal behavior from this reaction rather chemical type. To prove/disprove this hypothesis, SFC was measured as an important factor for assessing the melting behavior of the samples.

SFC values of CB, CIS and EIS are shown in Table 5. Based on the results in Table 5 all SFC values and the rate of their alteration are dependent on both FAC and temperature. Also, as shown in Table 4, the amounts of saturated fatty acids in CB is higher $(60 \%)$ than two other samples (EIS and CIS; approx. 34\%) and thereby the SFC values in CB are much higher than CIS and EIS in all analyzed temperatures. According to Table 5, moreover, increasing in temperature induced decreasing SFC in all samples. Similar result had previously com- mented by Karabulut et al. [10]. The SFC profiles also indicated that both CIS and EIS were completely melted at $35^{\circ} \mathrm{C}$ $40^{\circ} \mathrm{C}$, like $\mathrm{CB}$. This property is one of the key quality factors in chocolate products where the fat should almost completely melt at body temperature $\left(37^{\circ} \mathrm{C}\right)$. Our results show that neither CIS, nor EIS had thermal behavior similar to that of CB (Table 5). CB is character- ized by a rapid decrease (from $78.6 \%$ to $8.49 \%$ ) in $\mathrm{SFC}$ at $20^{\circ} \mathrm{C}$ $30^{\circ} \mathrm{C}$. A rapid decrease in $\mathrm{SFC}$ content from $18.5 \%$ to $3.57 \%$ within this temperature range $\left(20^{\circ} \mathrm{C}-30^{\circ} \mathrm{C}\right)$ is shown for EIS, whereas, SFC profile of CIS showed a rapid decrease (from $25 \%$ to $13.9 \%$ ) at $10^{\circ} \mathrm{C}-15^{\circ} \mathrm{C}$ (Table 5). Therefore, EIS shows thermal behavior closer to that of CB in comparison with CIS. Furthermore the SFC values of this sample are much lower (34\%) than that of $\mathrm{CB}(96.1 \%)$ in refrigerated temperature $\left(4^{\circ} \mathrm{C}-7^{\circ} \mathrm{C}\right)$, but the chocolate product with a certain level of this sample as CBR will not brittle during storage at refrigeration conditions, which is one of the most important quality factors in these products [16].

\section{Conclusion}

From this study we concluded that, combination of dry fractionation, partial hydrogenation and enzymatic interesterification is the proper method for producing CBR from tea seed oil. Also, the sample prepared with this method (EIS), for the lower SFC value than that of CB, is suitable for producing the chocolate products with soft texture. Furthermore, the lower SFC of this sample (34\%) in comparison with $\mathrm{CB}(96.1 \%)$ in refrigerated temperature $\left(4^{\circ} \mathrm{C}-7^{\circ} \mathrm{C}\right)$, induces the chocolate containing certain level of this sample, as CBR, will not brittle during storage at refrigeration conditions, which is one of the most important quality factors in chocolate product.

\section{Acknowledgements}

The authors are grateful to the Tarbiat Modares Univer- 
Table 5. Solid fat content (\%) of cocoa butter, enzymatically interesterified sample (EIS) and chemically interesterified sample (CIS) determined by nuclear magnetic resonance.

\begin{tabular}{ccccccccc}
\hline \multicolumn{7}{c}{ SFC \% } \\
\hline Oil samples & $5^{\circ} \mathrm{C}$ & $10^{\circ} \mathrm{C}$ & $15^{\circ} \mathrm{C}$ & $20^{\circ} \mathrm{C}$ & $25^{\circ} \mathrm{C}$ & $30^{\circ} \mathrm{C}$ & $35^{\circ} \mathrm{C}$ & $40^{\circ} \mathrm{C}$ \\
CB & $96.10 \pm 0.10^{\mathrm{a}}$ & $94.80 \pm 0.10^{\mathrm{a}}$ & $88.50 \pm 0.30^{\mathrm{a}}$ & $78.60 \pm 0.30^{\mathrm{a}}$ & $26.90 \pm 0.30^{\mathrm{a}}$ & $8.49 \pm 0.02^{\mathrm{a}}$ & $0.76 \pm 0.03^{\mathrm{a}}$ & 0 \\
EIS & $34.0 \pm 0.10^{\mathrm{b}}$ & $29.90 \pm 0.30^{\mathrm{b}}$ & $23.90 \pm 0.20^{\mathrm{b}}$ & $18.50 \pm 0.30^{\mathrm{b}}$ & $9.91 \pm 0.02^{\mathrm{b}}$ & $3.57 \pm 0.03^{\mathrm{b}}$ & $0.37 \pm 0.01^{\mathrm{b}}$ & 0 \\
CIS & $30.50 \pm 0.50^{\mathrm{c}}$ & $25.00 \pm 0.20^{\mathrm{c}}$ & $13.90 \pm 0.30^{\mathrm{c}}$ & $8.72 \pm 0.03^{\mathrm{c}}$ & $3.34 \pm 0.04^{\mathrm{c}}$ & $0.79 \pm 0.02^{\mathrm{c}}$ & 0 & 0 \\
\hline
\end{tabular}

CISs, chemically interesterified samples; EISs, enzymatically interesterified samples; CB, cocoa butter; Each value in the table represents the mean \pm standard deviation of triplicate analysis; Different superscripts within a column represent significant difference at $P<0.05$.

sity and Scientific Center of Excellent: Recycling and Losses of Strategic Agricultural Products for support this research.

\section{REFERENCES}

[1] K. J. Liu, H. M. Chang and K. M. Liu, "Enzymatic Synthesis of Cocoa Butter Analog through Interesterification of Lard and Tristearin in Supercritical Carbon Dioxide by Lipase," Food Chemistry, Vol. 100, No. 4, 2007, pp. 13031311. doi:10.1016/j.foodchem.2005.12.010

[2] M. A. Sahari, D. Ataii and M. Hamedi, "Characteristics of Tea Seed Oil in Comparison with Sunflower and Olive Oils and Its Effect as a Natural Antioxidant," Journal of American Oil Chemists' Society, Vol. 81, No. 6, 2004, pp. 585-588.

[3] M. Fazel, M. A. Sahari and M. Barzegar, "Determination of Main Tea Seed Oil Antioxidants and their Effects on Common Kilka Oil," International Food Research Journal, Vol. 15, No. 1, 2008, pp. 209-217.

[4] A. Rajaei, M. Barzegar and Y. Yamini, "Supercritical Fluid Extraction of Tea Seed Oil and Its Comparison with Solvent Extraction," European Food Research and Technology, Vol. 220, No. 3-4, 2005, pp. 401-405. doi:10.1007/s00217-004-1061-8

[5] E. Fattahi-far, M. A. Sahari and M. Barzegar, "Interesterification of Tea Seed Oil and Its Application in Margarine Production," Journal of American Oil Chemists' Society, Vol. 83, No. 10, 2006, pp. 841-845.

[6] H. X. Wang, H. Wu, C. T. Ho and X. C. Weng, "Cocoa Butter Equivalent from Enzymatic Interesterification of Tea Seed Oil and Fatty Acid Methyl Esters," Food Chemistry, Vol. 97, No. 4, 2006, pp. 661-665. doi:10.1016/j.foodchem.2005.04.029

[7] M. Ünsal and N. Aktaş, "Fractionation and Characterization of Edible Sheep Tail Fat," Meat Science, Vol. 63, No. 2, 2003, pp. 235-239. doi:10.1016/S0309-1740(02)00074-8

[8] M. Jamshidian, M. A. Sahari and M. Barzegar, "Modified Milk Fat as Food Ingredients," Journal of Food Science and Technology, Vol. 44, No. 3, 2007, pp. 338-341.

[9] S. Schmidt, S. Hurtova, J. Zemanovic, S. Sekretar, P.
Simon and P. Ainsworth, "Preparation of Modified Fats from Vegetable Oil and Fully Hydrogenated Vegetable Oil by Randomization with Alkali Catalysts," Food Chemistry, Vol. 55, No. 4, 1996, pp. 343-348. doi:10.1016/0308-8146(95)00113-1

[10] I. Karabulut, S. Turan and G. Ergin, "Effects of Chemical Interesterification on Solid Fat Content and Slip Melting Point of Fat/Oil Blends," European Food Research and Technology, Vol. 218, No. 3, 2004, pp. 224-229. doi:10.1007/s00217-003-0847-4

[11] H. Zhang, X. Xu, J. Nilsson and H. Mu, "Production of Margarine Fats by Enzymatic Interesterification with Silicagranulated Thermomyces lanuginosa Lipase in a LargeScale Study," Journal of American Oil Chemists' Society, Vol. 78, No. 1, 2001, pp. 57-64.

[12] AOCS, "Official Methods and Recommended Practices of the American Oil Chemists' Society," 4th Edition, AOCS Press, Urbana, 1996.

[13] L. C. Metcalf, A. A. Schmirz and J. R. Pelka, "Rapid Preparation of Methyl Esters from Lipid for Gas Chromatography," Analytical Chemistry, Vol. 38, No. 3, 1966, pp. 514-515. doi:10.1021/ac60235a044

[14] I. S. M. Zaidul, N. A. Nik Norulaini, A. K. Mohd Omar and R. L. Smith, "Supercritical Carbon Dioxide $\left(\mathrm{SC}-\mathrm{CO}_{2}\right)$ Extraction and Fractionation of Palm Kernel Oil from Palm Kernel as Cocoa Butter Replacers Blend," Journal of Food Engineering, Vol. 73, No. 3, 2006, pp. 210-216. doi:10.1016/j.jfoodeng.2005.01.022

[15] L. Tang, E. Bayer and R. Zhuang, "Production, Properties and Use of Chinese Tea Seed Oil," Fett Wissenschaft Technology, Vol. 95, No. 1, 1993, pp. 23-27. doi:10.1002/lipi.19930950107

[16] H. T. Osborn and C. C. Akoh, "Enzymatically Modified Beef Tallow as a Substitute for Cocoa Butter," Journal of Food Science, Vol. 67, No. 7, 2002, pp. 2480-2485. doi:10.1111/j.1365-2621.2002.tb08762.x

[17] R. D. Abigor, W. N. Marmer, T. A. Foglia, K. C. Jones, R. J. Diciccio, R. Ashby and P. O. Uadia, "Production of Cocoa Butter-like Fats by the Lipase-catalyzed Interesterification of Palm Oil and Hydrogenated Soybean Oil," Journal of American Oil Chemists' Society, Vol. 80, No. 12, 2003, pp. 1193-1196. 